\author{
Kazimierz Starzyk \\ Wyższa Szkoła Bankowa w Poznaniu \\ e-mail: starzyk.k@gmail.com
}

\title{
THE DILEMMAS OF CHINA`S MARKET \\ INCOMPLETE TRANSFORMATION - THE WORLD ECONOMY PERSPECTIVE
}

\section{DYLEMATY NIEDOKOŃCZONEJ TRANSFORMACJI CHIŃSKIEJ GOSPODARKI Z PERSPEKTYWY GOSPODARKI ŚWIATOWEJ}

DOI: 10.15611/pn.2018.523.32

JEL Classification: D63, G01, F13, P27

Summary: The Chinese case suggests that the market transition is possible without a parallel transformation of the political system. The opposite case is that of Central European economies, where systemic political and institutional changes initiated the market transition processes. Thus, the Chinese pattern of transition can be called gradual, where the main objective is to build a market economy while keeping the single-party authoritarian political system. It bears fundamental implications upon the very process of market transformation making it gradual without a clear formulation of systemic goals at the outset of the process. The aim of the paper is to present the development problems faced by the Chinese economy now which solution determines the future position of China in the world economy. The text considers, among other things, the dilemma of authoritarian political system versus democracy, economic efficiency versus social justice and the challenges following the financial crisis 2007/8+.

Keywords: world economy, market transformation, open economy strategy, economic efficiency, crisis, China.

Streszczenie: Chińskie doświadczenia pokazują, że rynkowa transformacja gospodarki może zachodzić także w oderwaniu od przemian systemu politycznego. Próbując w związku z tym wyodrębnić zjawisko rynkowej transformacji w postaci tzw. socjalistycznej rynkowej transformacji gospodarki, dochodzimy do wniosku, że kluczem do takiego wyodrębnienia są również zachodzące w gospodarce procesy podwyższające efektywność gospodarowania, generowane przez wprowadzone do niej mechanizmy rynkowe, z zachowaniem jednak podstaw ideologicznych z okresu gospodarki planowej w dziedzinie sprawowania władzy. Celem artykułu jest przedstawienie aktualnych problemów rozwoju chińskiej gospodarki, których rozwiązanie determinuje przyszłą jej pozycję w gospodarce światowej. Przedmiotem analizy jest m.in. dylemat monopartyjnego systemu władzy, dylemat efektywności gospodarowania versus sprawiedliwości społecznej oraz wyzwania związane z następstwami kryzysu finansowego 2007/8+. 
Słowa kluczowe: gospodarka światowa, transformacja rynkowa, strategia rozwoju otwartego, efektywność gospodarowania, kryzys finansowy, Chiny.

\section{Introduction}

The key to the sustainable development of the Chinese economy is the effective use of both internal and external factors of growth (foreign trade, capital and technology transfers) within a framework of consistently implemented open economy strategy. This gave way to the long period of GDP growth, against a background of major technological changes. This has assured the rise of the economy's international competitiveness and eventually led to a rise in social welfare. Looking from the point of view of the historical world economy's development people regard these changes as unprecedented.

The inexorable economic rise of China over the last four decades synthetically expressed through an average annual rate growth ranging at about 10 per cent has elevated the country to the second position among world economies just behind the US. The scenario of China forcing its way ahead of the United States as the leading economy, is now becoming quite real and can be expected within a 15-20 year perspective, as anticipated by the World Bank, IFM, and respected consulting firms.

The key to this legitimate estimate is economic development taking place in China within market transition processes. They, however specifically, aim to achieve economic and social transformation targets within the framework of a mono-party political system which in practice means authoritarian management of the economy. The recent political decisions approved by Chinese Communist Party petrify it.

As a result, a theoretical dilemma arises, whether a market transformation can go through effectively without the existence of an underlying systemic transition. This dilemma, which in essence suggests a shift towards a political pluralism (democracy), goes hand in hand with a number of other predicaments among which the most visible ones are: the choice between economic efficiency and social equity, narrowing down of Chinese regional disparities between east, west and central provinces, eradication of socio-economic underdevelopment of Chinese rural areas, a reorientation of the so far implemental export oriented strategy towards the more internal market oriented one due to the world financial crisis, threats caused by the Trump's protectionist trade policy.

The goal of this text is to present the challenges faced by China now, which affect its future position in the world economy. The top issue in the article is the transition to democracy. 


\section{Economic problems connected with building a political party system}

The most serious dilemma of the Chinese market transition is connected with further socio-economic changes, which comes down to a question whether achieving the aims of a market transformation, that means a sustainable raise of economic efficiency, is possible only through pursuing reforms leading to the reference model of the capitalist economy or whether the creation of an efficient market economy can also occur in a socialist - capitalist mixed economic pattern (as we see it in China).

To put it differently, can the process of market transformation of an economy also effectively take place in the so-called socialist market economy? Then can the economic objectives (as in capitalism) be understood as achieving a progressively higher level of economic efficiency, as expressed in terms of national income growth, technological progress, growth of international competitiveness, where all ultimately result in an increase of living standards of the population?

So far, the findings in the field of economic transformation would claim it impossible. Scientific works on the subject of transition from planned to market economy, stipulate a simultaneous transformation of the political system from the authoritarian one to democracy. In fact, we can say that they expose the latter as a cardinal precondition of market transformation. In the meantime, China's economic transformation processes develop under a one-party political mechanism, which is reflected by the full authoritarian power of China's Communist Party. There is little to suggest that this should change in the foreseeable future. Reversely, we can expect the strengthening of the mono-party system and its authoritarian nature.

However, the case of China shows it is possible to separate the market transformation as an autonomous phenomenon, defined as a creation of a market economy without a full systemic transformation and strengthening the role of the mono-party system; more precisely - without the implementation of a democratic political system. As a result, China's case undercuts the widely shared notion that fundamental changes of the political system are imperative to the construction of a market-based economy. It shows that market-based economy can be set up without extensive systematic changes depicting that the state exercises strong power with a proven track of market reforms that eventually lead to a new economic order but with one-party governing system maintained [Starzyk 2009].

However, the case of China raises a fundamental dilemma: is that model of market transition efficient in the long-run, or should it be changed in order to achieve long term development objectives possible only through full systemic transformation as it is considered in subject literature [Lavigne 1995; Balcerowicz 1997; Szczepański 1999; Starzyk 2009]?

While looking at the dilemma, it should be stressed that so far the implementation of socio-economic objectives in China has been under an authoritarian system, 
a concept which in fact is not alien to the emerging East Asian economies. We know that authoritarianism was, at some point in their socio-economic development history, an effective tool in projecting control to stimulate and accelerate their economic development [Starzyk (ed.) 2001]. We assume that East Asian and Chinese experience in the field of market transformation can be used in the case of countries opposing market transformation, for example Cuba and North Korea [Starzyk 2015].

Although the Chinese case shows that it is possible to gradually build a market economy within a socialist system, an unanswered question remains: can we regard such a model of economic market transformation as its final phase? Or is political pluralism inevitable to create sustainable conditions for rising economic efficiency and this way to improve the standard of living of the population? These questions give rise to another dilemma namely the choice between economic efficiency and social justice.

\section{Social justice versus economic efficiency}

It is known the long-term Chinese development strategy promotes social goals in the first place. This is the key element of the Chinese current declarations with regards to long political and economic objectives. However, past experiences clearly show that Chinese economic policy is dominated by motives related to the increase of economic efficiency. In other words, the choices made between investment and consumption are skewed in favour of investment [Starzyk 2009].

It is against this background, that a question comes up whether the continued high-rate of real income of the population will not cause a collision between consumption demand and investment demand. It is known the latter determines the continued modernization of the economy, as well as the development of the resource base, agriculture, etc. This creates a dilemma of choice between investment and consumption, and thus also reconciliation of the requirement of increasing economic efficiency with social justice.

This predicament would be especially visible in the event of any significant slowdown of GDP growth due to currently prolonging global financial crisis, or a possible new crisis, initially located in East Asia and generated in China.

At this point it should be emphasized that as a result of social tensions seen in China, a growing consumption would change the GDP structure at a cost of decreased investment which would, on the other hand, decrease country's development capacity (also in response to a possible economic crisis).

As a consequence, for example, the ability of the economy to narrow down the inter-regional disparities between eastern, western and central areas of China may lower. This causes another serious development dilemma, as it is directly connected to the choice between of investment policies and social policies. Both policies are responsible for bringing the regional living standards up to one level. The former is responsible for stimulating the rate of growth while the latter for solving social 
problems. The dilemma is: how to make these two policies integrate together for implementing the long term goal of bringing the living standards to a higher level?

These regions absorb more funds, but their share in total capital investment is much greater than their relative share in GDP. It should be emphasized, however, that the investments coming from the centrally planned pool are made primarily in the area of infrastructure and go primarily into the construction of roads, railways, airports as well as hydropower and gas pipelines. This explains to some extent the phenomenon of low efficiency of investment in rural western and central provinces against the investment in the much more urbanized eastern provinces [The Economist February 2018].

The division between the "town" and "village" has a regional dimension: The eastern part of China (along the east coast) shows the highest degree of urbanisation. It is also the most developed area of China. Western provinces are relatively much less developed and characterised by a relatively lower degree of urbanization. In addition, the rate of increase in income in rural areas is much slower than in urban ones. This is due to the fact that labour productivity in Chinese agriculture is much lower than in industry. It is the result of lower capital intensity, lower level of knowledge and skills, and worse general health of the rural population, which consequently leads to less motivation to take up economic activities (trade, business) and an increase in migration from the countryside to the city as well as abroad.

\section{China and the economic crisis $2007 / 8+$}

The global economic crisis affected among others the East Asian economies, including China, despite the country's very good economic and financial condition at the turn of the years $2007 / 8$ - that is at the time when the crisis was already well under way in the United States.

The transition of the economic crisis to East Asia carries very serious implications for the future development of the world economy, which is precisely in Asia, especially East Asia and India, and also increasingly in the Gulf countries, where the future of the world economy is shaped.

One has no choice but to agree with Zbigniew Brzezinski, that, among the three most important changes taking place in the world, alongside global political awakening causing the social mobilisation of the entire global population with its common global problems (e.g., climate and environment, poverty and injustice, terrorism), it is the matter of shift of the global power centre from the Atlantic world to the East Asia [Brzeziński, Scowcroft 2008]. A key role is played here, alongside Japan, by Asian, emerging economies, among which most important are China and India together with the so-called Asian Tigers - South Korea, Taiwan, Hong Kong and Singapore, which were joined in the 1980s by Malaysia, Indonesia and Vietnam.

In this situation, when the economic development centre is moving to Asia, especially Eastern Asia and China in particular, economists become ever more 
interested in the economic events in this area having an impact on the whole stability of the world economy which is still struggling with the aftermath of the global financial crisis, because its solution is largely dependent on the development of economic relations between the U.S. and East Asian economies, especially China. This is because East Asian economies were the target of $22 \%$ of US exports and the source of $32 \%$ of imports in the critical year 2008. Top trade partners in the region were: China (16\% of total imports and 5\% of total exports in 2008), Japan (7\% and $5 \%$ ) and South Korea (2\% and 3\% respectively). The United States has a trade deficit practically with all major economies of East Asia. It is worth mentioning that China's share in the US deficit relating to trade in goods amounted to $28 \%$ in 2008. What is more evident is that East Asia also plays an important role in the U.S. capital flows. Its share of the United States FDI outflow sums up to about 10$12 \%$ (average annual flow during the last 10 years) and about $12 \%$ when it comes to return generated by OFDI (as at the end of 2008). Similarly, liabilities on OFDI reached $12 \%$ (as at the end of 2008 with most investments coming from Japan). Other important financial flows include portfolio investment (China is one of the major buyers of U.S. Treasury bonds. In June 2009, their value reached about 764 billion U.S. dollars) [Starzyk 2013].

Just like for the US, East Asia economies play an important role in trade and capital flows of the European Union. In 2008, the share of the major East Asian economies in total exports of the EU-27 was about 17\% (19\% in 2000; EU-15) while in the import of goods about $28 \%$ (28\% in 2000; EU-15). Overall recorded deficit was quite high with East Asian countries, especially China. The only other surplus recorded in 2008 concerned Eastern Asian larger economies - South Korea, Hong Kong and Singapore. However, it was relatively small.

East Asian countries are also the main destination of European business investments. In 2008 the share of the largest countries in East Asia in FDI outflows from the European Union stood at $18-20 \%$.

With regard to the data of 2008 , we have to point to the substantial level of economic interdependence between the U.S. and the European Union and the East Asian economies, especially China. This, at a time of crises, means a transfer of the economic shocks and, consequently, their further deepening. On the other hand, once the crises is over in the U.S., in the EU, and first of all in East Asia, especially in China, a beneficial impulse can be observed for the entire world economy.

In this context the situation of the Chinese economy is quite interesting. In 2009 it reached 8\% GDP growth, even though consumer demand in the United States remained at a low level. The case is worth a closer analysis, because its time horizon goes beyond. In fact it can also be seen in a broader context, namely, a dependence of China's export and GDP growth on U.S. consumer demand. According to The Economist [The Economist 2009] the dependence of growth of the Chinese economy on the U.S. consumer demand is a myth. The author of the article argues that if China's exports to the U.S. are measured in terms of value added (i.e. after 
the deduction of import input into export), then it turns out that China's exports to the U.S. accounts for only 5\% of the total value of Chinese GDP, which leads to the conclusion that the achievement of $8 \%$ GDP growth in 2009 and its continuation in subsequent years has been more dependent on trade with other partners than the U.S., namely the EU and the countries of East Asia.

To some extent, East Asian economies have been spared a deeper economic downslide due to a decline of exports, especially in 2008, by a fall in prices of imported crude oil, accompanied by a decrease in energy consumption. According to The Economist the resulting benefits for Asia can be estimated at about 3\% of their GDP. Lack of data limits further conclusions in this respect.

The above mentioned factors, coupled with a decline in prices of food products, created a relatively favourable environment for East Asian economies to counter the global economic crisis. This does not mean, however, that we are now (early 2018) in the position to answer the question of whether East Asian economies have already successfully dealt with the effects of the global financial crisis. What is more, a deeper crisis may come causing bigger then so far, regional economic and social problems of the East Asian economies, including China.

\section{Instead of the conclusions}

If the hypothesis about a possible downward trend in Chinese exports is right - that it would be caused by a sharp downturn in the economies of East Asia because of the new Asian financial crisis - then a deceleration of the inflow of foreign direct investment into the Chinese economy could bring about a decline of Chinese imports. This in turn would adversely affect, in the medium term, the level of foreign exchange reserves, and in the longer term would reduce the rate of growth of GDP, which on the one hand still depends on the growth rate of exports and yet, on the other, the imports of capital goods, which is a carrier of new technology - a source of growth of industrial production dictating the growth of GDP.

In such a situation, while having in mind the Trump's protectionist trade policy, theoretically speaking the devaluation of renminbi might be expected although in the light of current hard arguments in favour of currency revaluation it is almost paradoxical. However, this does not solve the structural problems of the growing Chinese economy, and could cause serious perturbations in global markets. In practice, in the medium term, devaluation is not an option, chiefly because of the high Chinese currency reserves. Their significant reduction could only be decided in response to a fall in Chinese exports levels. Here the behaviour of the terms of trade would serve as a key indicator. Its worsening would mean reduced benefits from international goods exchange and would justify measures taken to compensate the losses by boosting exports, using in the extreme case the devaluation mechanism.

However, a different scenario is possible. A fall in prices of factors of production e.g. raw materials and industrial products (including half-finished goods) imported 
by China would very likely offset a possible new financial crisis. When assessing the impact of any new financial crisis on the Chinese economy an opposite hypothesis may be put forward at the same time. A lot depends on the future world economy developments, which the US - China economic and political relations play a fundamental role in.

\section{References}

Balcerowicz L., 1997, Socjalizm, kapitalizm, transformacja. Szkic z przełomu epok, PWN, Warszawa. Brzeziński Z., Scowcroft B., 2008, America and the World. Conversations on the Future of American Foreign Policy (Moderated by D. Ignatius), Basic Books, New York.

Cambell K.M., Ratner E., 2018 March/April, The China Reckoning. How Beijing Defied American Expectations, Foreign Affairs.

Lavigne M., 1995, The Economics of Transition: from Socialist Economy to Market Economy, Red Globe Press, London.

Starzyk K. (ed.), 2001, Zagraniczne inwestycje bezpośrednie w gospodarkach Azji Pacyfiku, Wydawnictwo Naukowe Semper, Warszawa.

Starzyk K., 2009, Zagraniczna polityka ekonomiczna w procesie rynkowej transformacji gospodarki. Przypadek Chin, Wydawnictwo PLACET, Warszawa.

Starzyk K., 2015, Pozaeuropejskie gospodarki oporne transformacji rynkowej. Przypadek Korei Ptn., [in:] B. Drelich-Skulska, M. Domiter, W. Michalczyk (eds.), Jabłko niezgody. Regionalne wyzwania wspótczesnej gospodarki światowej, Wydawnictwo Uniwersytetu Ekonomicznego we Wrocławiu, Wrocław.

Starzyk K., 2013, Region Azji Pacyfiku w warunkach kryzysu 2008+, [in:] K. Żukrowska (ed.), Kryzys gospodarczy 2008+. Test dla stosowanej polityki, Oficyna Wydawnicza Szkoły Głównej Handlowej w Warszawie, Warszawa.

Szczepański J., 1999, Reformy, rewolucje, transformacje, Wydawnictwo IFiS PAN, Warszawa.

The Economist, 2009, May 16, Asian economies. Crouching tigers, stirring dragons.

The Economist, 2018 February 24, China, regional development - the woes of the rust belt.

The Economist, 2018, March 10th, Trump 's tariffs - The threat to world trade. 